\title{
Potential Export of Indonesian Products Based on Perception of Indonesian Migrant Workers in Hongkong
}

\author{
Ma'mun Sarma ${ }^{1}$, Stevia Septiani ${ }^{2}$, Edward H. Siregar $^{3}$, Herien Puspitawati ${ }^{4}$ \\ \{msarma@apps.ipb.ac.id ${ }^{1}$, steviaseptiani@apps.ipb.ac.id² ${ }^{2}$ edwardsiregar57@gmail.com³ \\ herien@apps.ipb.ac.id $\left.{ }^{4}\right\}$ \\ Department of Management, Faculty of Economics and Management, IPB University ${ }^{123}$, and \\ Department of Family and Consumer Sciences, Faculty of Human Ecology, IPB University ${ }^{4}$
}

\begin{abstract}
Indonesian Migrant Worker (IMWs) can also be used to provide product information from Indonesia that is available in the city where IMWs works. This is very helpful for identifying products made in Indonesia that are available abroad. This research aims to explore the export potential of Indonesianmade products based on IMWs perceptions. This research is a case study with 50 IMWs in Hong Kong. Data analysis uses descriptive statistics. Research results show that products made in Indonesia are available at supermarkets and grocery markets in Hong Kong such as herbs (spicy kitchen), instant noodles, instant drinks, snacks, body treatments, medicine and others. The products found in supermarkets and grocery markets in Hong Kong can be used as a potential export of Indonesian-made products in Hong Kong.
\end{abstract}

Keywords: Hong Kong, Indonesian Migrant Workers (IMWs), Indonesian Product, export

\section{Introduction}

Indonesian Migrant Workers (IMWs) play an important role in absorbing labor and earning foreign exchange for the government. Until now, the number of IMWs abroad has reached a very large number, which is around 8 million people. If the assumption is that the minimum wage is $10-20$ million rupiah a year per person, the country's foreign exchange entry is at least in the range of IDR 160 trillion a year (Indonesia.go.id 2019). The large contribution to the country's foreign exchange earnings makes the foreign exchange generated by this IMWs in the second position after the oil and gas sector. Based on data held by the Indonesian Migrant Workers Protection Agency, it is known 
that IMWs is spread across more than 25 countries. In the April 2018-2020 period, it was known that Malaysia, Taiwan and Hong Kong were still the main destinations for IMWs. If in 2018 the IMWs in Malaysia reached 8,445; Taiwan 5,186; and Hong Kong 4,984; Similar numbers also occurred in 2019 where IMWs in Malaysia reached 7,121; Taiwan 7,213 and Hong Kong 6,155. It can be seen that compared to Malaysia and Taiwan, Hong Kong is a more attractive country for IMWs. However, it was contrary happened in 2020, it was noted that as of April 2020 IMWs dispatch were only aimed at 2 countries, namely Hong Kong with 1,715 people and Taiwan 632 people. Social restrictions due to the Covid-19 pandemic led the government to implement a moratorium on sending IMWs abroad. The full distribution of IMWs placements by country can be seen in Figure 1.

Apart from being a foreign exchange earner, the existence of IMWs can also provide other benefits, namely as a market intelligence related to export opportunities for Indonesian-made products in the countries where they work. Indonesia's export performance in May 2020 reached US \$ 10.53 billion or decreased by 28.95 percent compared to May 2019 (BPS 2020). BPS also stated that non-oil and gas contributed the largest number of exports from total exports in May 2020, reaching 93.81 percent, in which agricultural products, processing industries and mining experienced a significant decline both annually and monthly. China is the main destination country for non-oil and gas exports, which in May 2020 reached US \$ 2.21 billion.

Through IMWs who works in other countries, we can find out what products they usually consume and also the availability of these products in the countries where they are located. Therefore, this research aims to explore the export potential of Indonesian-made products based on the IMWs perception in Hong Kong. 


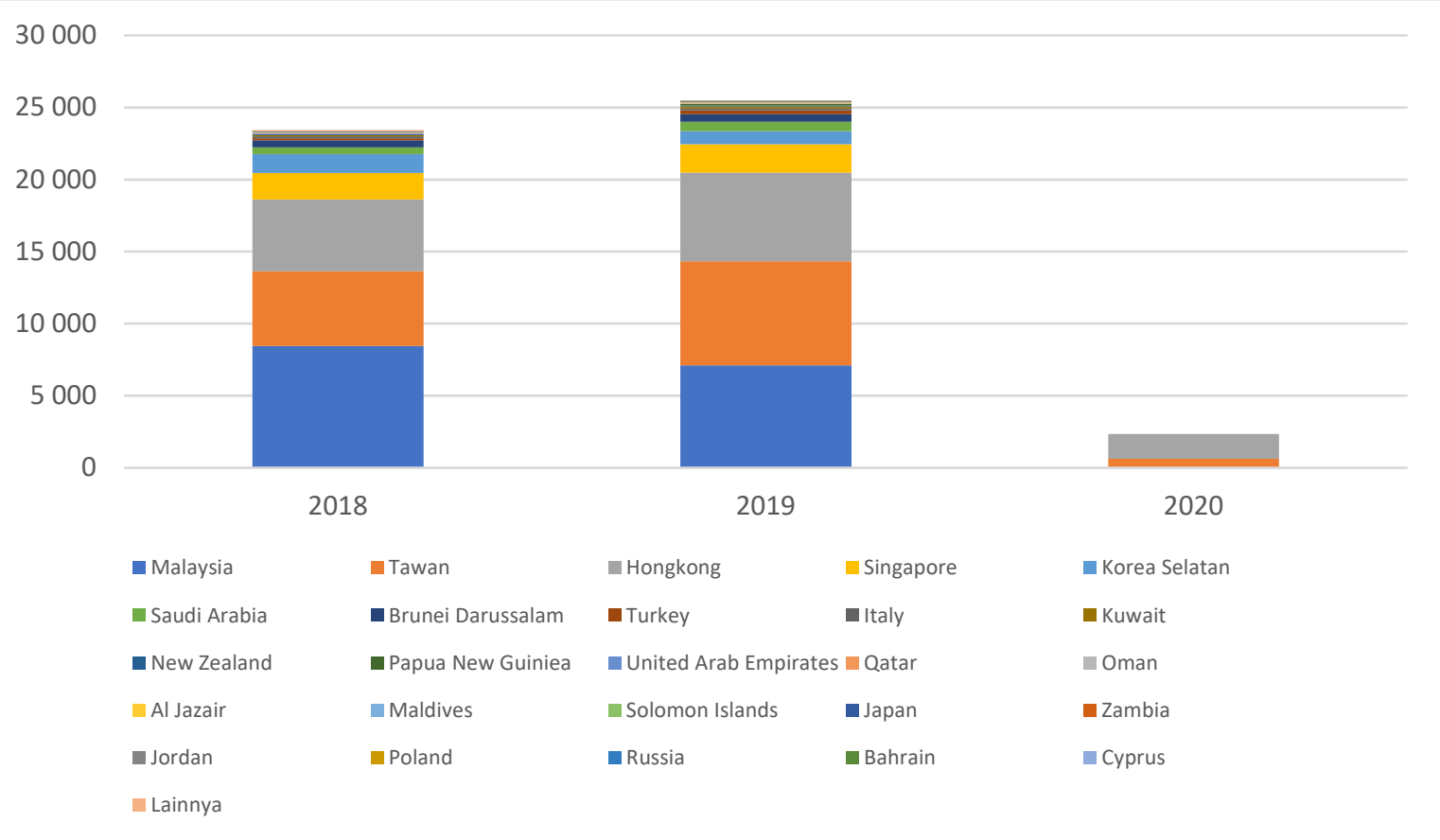

Figure 1. Placement of IMWs by country for the period 2018-2020 (April) Source: BP2MI (2020)

\section{Research Method}

This research was conducted on 26-30 October 2018 in Hong Kong. This research aims to explore the export potential of Indonesian-made products based on IMWs perceptions. The sampling method used was a non-probability sampling technique with a purposive sampling method. This technique is sampling by determining specific characteristics in accordance with the research objectives so that it is expected to be able to answer research problems. Research respondents focused on Indonesian Migrant Workers (IMWs) who came from various districts in Hong Kong. Data collection was carried out by distributing questionnaires and in-depth interviews with selected respondents. After data selecting and data cleaning, there were 50 respondents who could be further processed. Data analysis was carried out by descriptive statistic approach. The framework for this research is presented in Figure 2. 


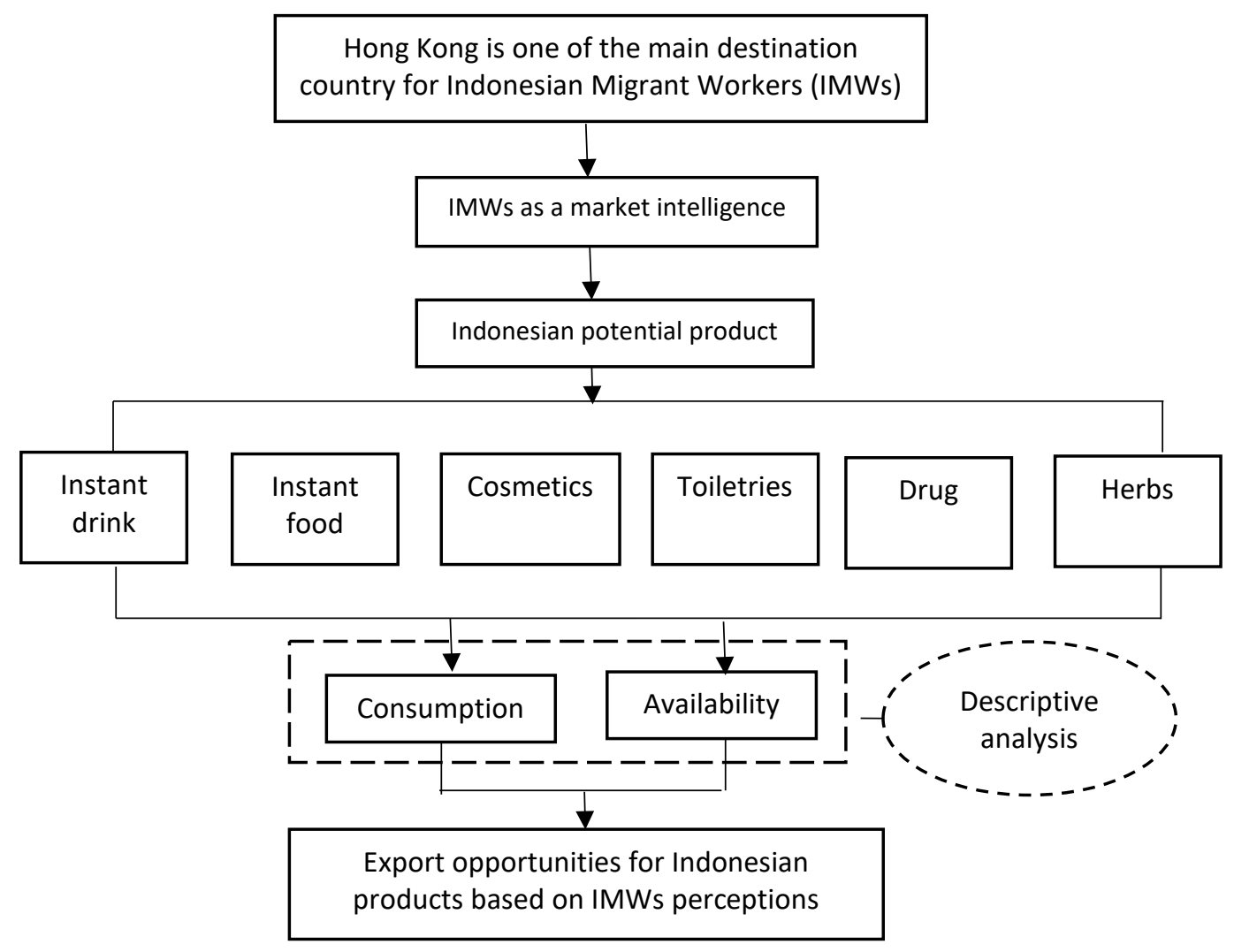

Figure 2. Research framework

\section{Results and Discussion}

\section{Respondent Characteristics}

As an initial stage in the descriptive analysis, a profile portrait of Indonesian Migrant Workers (IMWs) was carried out by identifying the characteristics of the respondents (see Table 1). IMWs which is the object of research is focused on female IMWs.

In general, the IMWs are married (46\%) and aged over 30 years to 40 years $(46 \%)$. However, $36 \%$ of them are $41-50$ years old. The IMWs age range is related to the demand of Hong Kong residents who prefer IMWs with an older age. This is because IMWs which is younger is considered relatively difficult to adapt to its users. The majority of them have worked in Hong Kong for a long 
time, namely for more than 5 years to 15 years $(60 \%)$ with income ranging from more than 7 million to 9 million rupiah per month (72\%). Hong Kong is one of the most popular destination countries for IMWs. This is because the IMWs salary in Hong Kong is quite large compared to other Asian countries. Although it is not easy to be accepted as IMWs in Hong Kong, Hong Kong's legal protections for foreign maids are quite strict and law enforcement is also well underway. This is what makes IMWs feel at home to work for a long time in Hong Kong.

Table 1 Respondent Characteristics

\begin{tabular}{llll}
\hline Criteria & Category & Frequency & Percentage (\%) \\
\hline Age & $21-30$ & 9 & 18 \\
& $31-40$ & 23 & 46 \\
& $41-50$ & 18 & 36 \\
\hline Subtotal & & 50 & 100 \\
\hline Length of work & Less than 1 year & 2 & 4 \\
& $1-5$ yrs & 17 & 34 \\
& $>5-10$ yrs & 21 & 42 \\
& $>10-15$ yrs & 9 & 18 \\
& $>15$ yrs & 1 & 2 \\
\hline Subtotal & & 50 & 100 \\
\hline Marital status & Single & 16 & 32 \\
& Married & 23 & 46 \\
& Widow & 11 & 22 \\
\hline Subtotal & & 50 & 100 \\
\hline Monthly Income & $5-7$ million & 10 & 20 \\
& $>7-9$ million & 37 & 74 \\
& $>9$ million -11 million & 3 & 6 \\
\hline Subtotal & & $\mathbf{5 0}$ & $\mathbf{1 0 0}$ \\
\hline
\end{tabular}

Source: Own data (2018)

\section{Preference for products from Indonesia}

If approached from a marketing point of view, IMWs is a consumer of products from Indonesia. They can also be seen as market intelligence in seeing the potential for export of products from Indonesia in Hong Kong. As many as 76 percent brought products from Indonesia when they went to Hong Kong. The reason is because they are used to using the product (54\%). This result is closely related to the consumer preference. Consumer preferences are defined as the subjective or individual tastes, as measured by utility (Guleria 2015). 
Table 2. Preference for products from Indonesia

\begin{tabular}{llll}
\hline Criteria & Category & Frequency & Percentage (\%) \\
\hline Bringing products from & Yes & 38 & 76 \\
Indonesia & No & 12 & 24 \\
\hline Subtotal & & 50 & 100 \\
\hline The reason for bringing & I used to use it & 27 & 54 \\
products from Indonesia & Others & 5 & 10 \\
& NA & 18 & 36 \\
\hline Subtotal & & 50 & 100 \\
\hline
\end{tabular}

Source: Own data (2018)

From Figure 3, it is seen that from the category of products from Indonesia, the products they prefer to carry out are personal care products such as toiletries, cosmetics and medicines (see Figure 3). This is understandable, considering that personal care products have a specific level of suitability for each person. Therefore, the product category is one of the most frequently brought by IMWs to the destination country of Hong Kong.

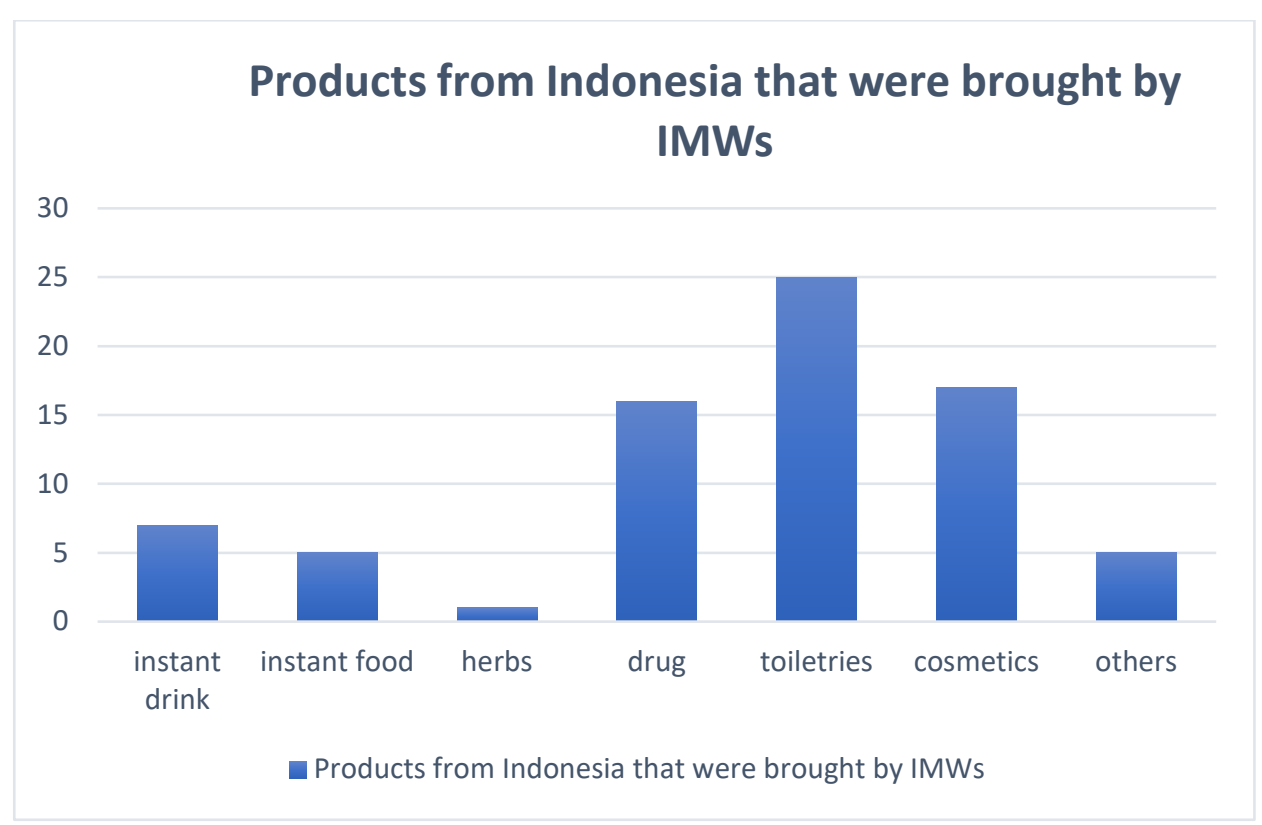

Note: each respondent may give more than one answer.

Figure 3. Categories of products from Indonesia brought to Hong Kong 


\section{Potential products from Indonesia in Hong Kong}

As previously discussed, the product categories brought by IMWs are included in personal care products which, in fact, will continue to be sought because of the unique characteristics of the product for each consumer. Furthermore, to see potential Indonesian products in Hong Kong, we asked respondents two questions regarding the use of Indonesian-made products and their reasons. There are 88 percent of IMWs stated that they use Indonesian products in Hong Kong (see Table 3). The reasons for using Indonesian products in Hong Kong include feeling that they are compatible with the product (20\%), guaranteed halalness (18\%) and love for Indonesian-made products $(10 \%)$.

Table 3. Potential products from Indonesia in Hong Kong

\begin{tabular}{llll}
\hline Criteria & Category & Frequency & Percentage (\%) \\
\hline Using Indonesian & Yes & 44 & 88 \\
products in Hong Kong & No & 3 & 6 \\
& NA & 3 & 6 \\
\hline Subtotal & & 50 & 100 \\
\hline Reasons for using & Purchased in Hong Kong & 1 & 2 \\
Indonesian products in & Love Indonesian products & 5 & 10 \\
Hong Kong & Halal & 9 & 18 \\
& It fits & 10 & 20 \\
& NA & 25 & 50 \\
\hline Subtotal & & 50 & 100
\end{tabular}

Cultural differences in Hong Kong create IMWs often selective in using all kinds of existing products. For example, Muslim IMWs will look for products that are guaranteed halal. Therefore, thet do not infrequently bring products from Indonesia that already have halal guarantees.

As we know, Fast Moving Consumer Goods (FMCG) products are divided into at least three categories, namely personal care, household care, and food and beverages. When they go to Hong Kong, there are more IMWs who carry personal care products, there is a slight difference in the product categories used while in Hong Kong. Apart from personal care products, FMCG categories such as instant food and drinks are the products from Indonesia that are most often consumed by IMWs while in Hong Kong. 


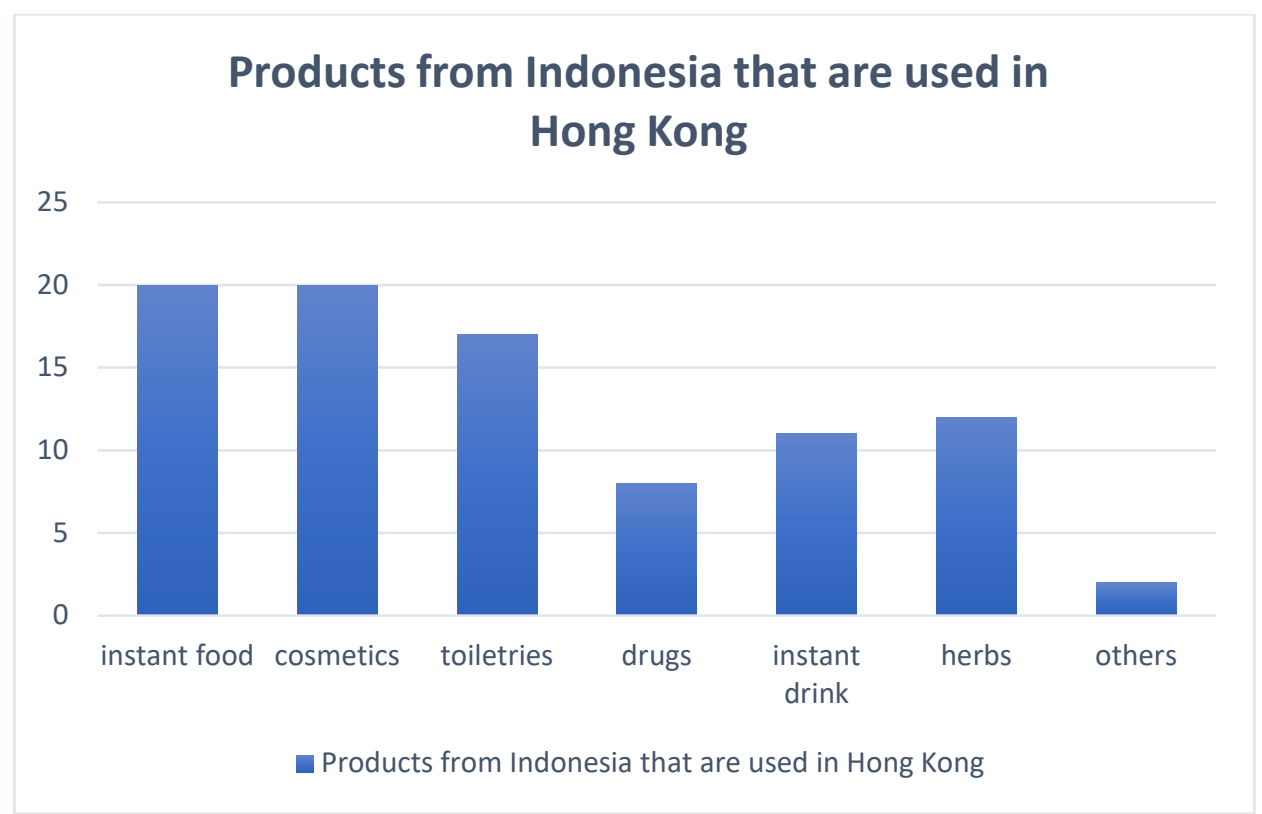

Note: each respondent may give more than one answer.

Figure 4. Indonesian product categories used in Hong Kong

\section{Market opportunity}

Market opportunity is seen in terms of target market and product potential. This is in line with Douglas and Craig (2009) which states that international marketing opportunities relating to consumption contexts and factors which vary across and within countries and influence behavior in these contexts.

Identification of the export potential of products from Indonesia can be seen from the market opportunities in Hong Kong. In this study, information was extracted on the number of family members at work, the presence of Indonesian-made products in the workplace and the presence of Indonesian products in Hong Kong shops / supermarkets. The majority of IMWs work in families with 1-3 family members (44\%) and 4-6 people (32\%). Indirectly, IMWs user family members become the target consumers of products made in Indonesia.

Most of the IMWs informed that there are products made in Indonesia in the homes where they work $(56 \%)$. The types of products most commonly 
found in IMWs' workplaces are kitchen spices, instant noodles, and snacks, respectively. This illustrates that in general these three types of products have potential demand opportunities for households in Hong Kong.

Table 4. Market opportunities for Indonesian products in Hong Kong

\begin{tabular}{|c|c|c|c|}
\hline Criteria & Category & Frequency & Percentage (\%) \\
\hline Number of family & $1-3$ & 22 & 44 \\
\hline members at work in & $4-6$ & 16 & 32 \\
\hline \multirow[t]{3}{*}{ Hong Kong } & $7-10$ & 3 & 6 \\
\hline & More than 10 & 1 & 2 \\
\hline & NA & 8 & 16 \\
\hline Subtotal & & 50 & 100 \\
\hline There are products & Yes & 28 & 56 \\
\hline made in Indonesia at & No & 20 & 40 \\
\hline home where you work & NA & 2 & 4 \\
\hline Subtotal & & 50 & 100 \\
\hline See Indonesian-made & Yes & 43 & 86 \\
\hline products at Hong Kong & No & 6 & 12 \\
\hline shops/supermarkets & NA & 1 & 2 \\
\hline Subtotal & & 50 & 100 \\
\hline
\end{tabular}

NA: Not Answer 


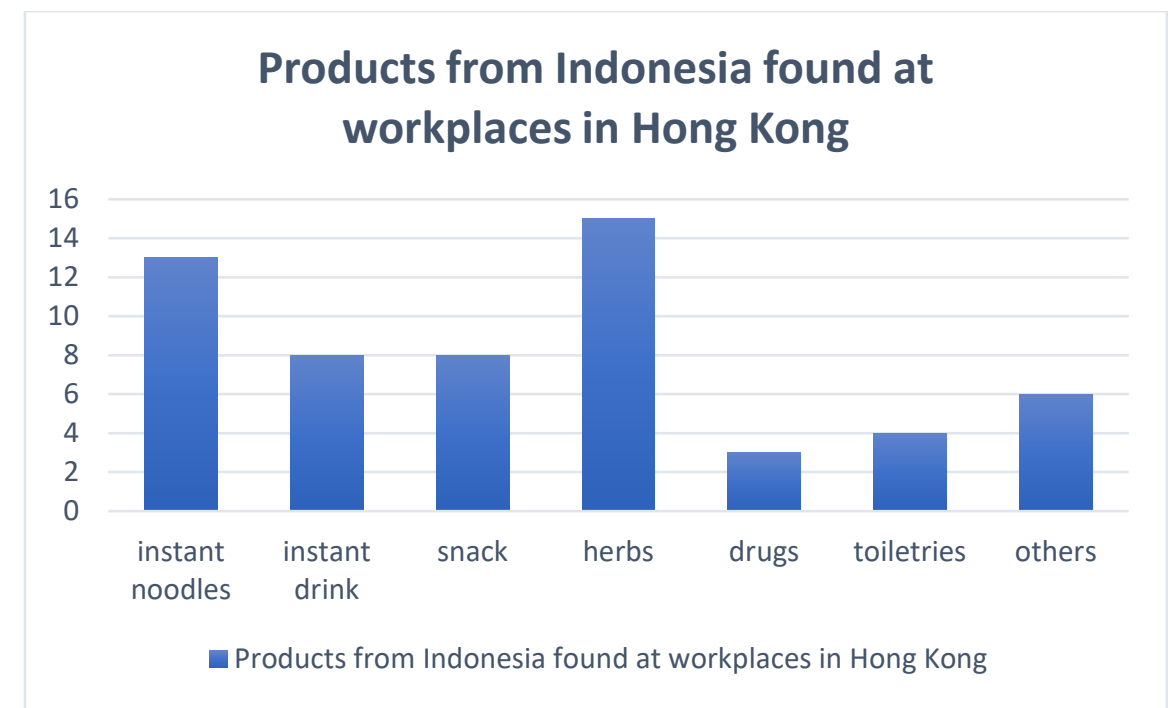

Note: each respondent may give more than one answer.

Figure 5. Categories of products from Indonesia found in the workplace at Hong Kong

In a broad sense, the potential for exporting products from Indonesia can be seen from the presence of Indonesian products in Hong Kong shops / supermarkets. Based on information provided by IMWs, food and beverage products such as instant noodles, kitchen spices and instant drinks are Indonesian products that are often found in Hong Kong shops / supermarkets. This illustrates that Indonesia's food and beverage products are easier to penetrate the export market. 


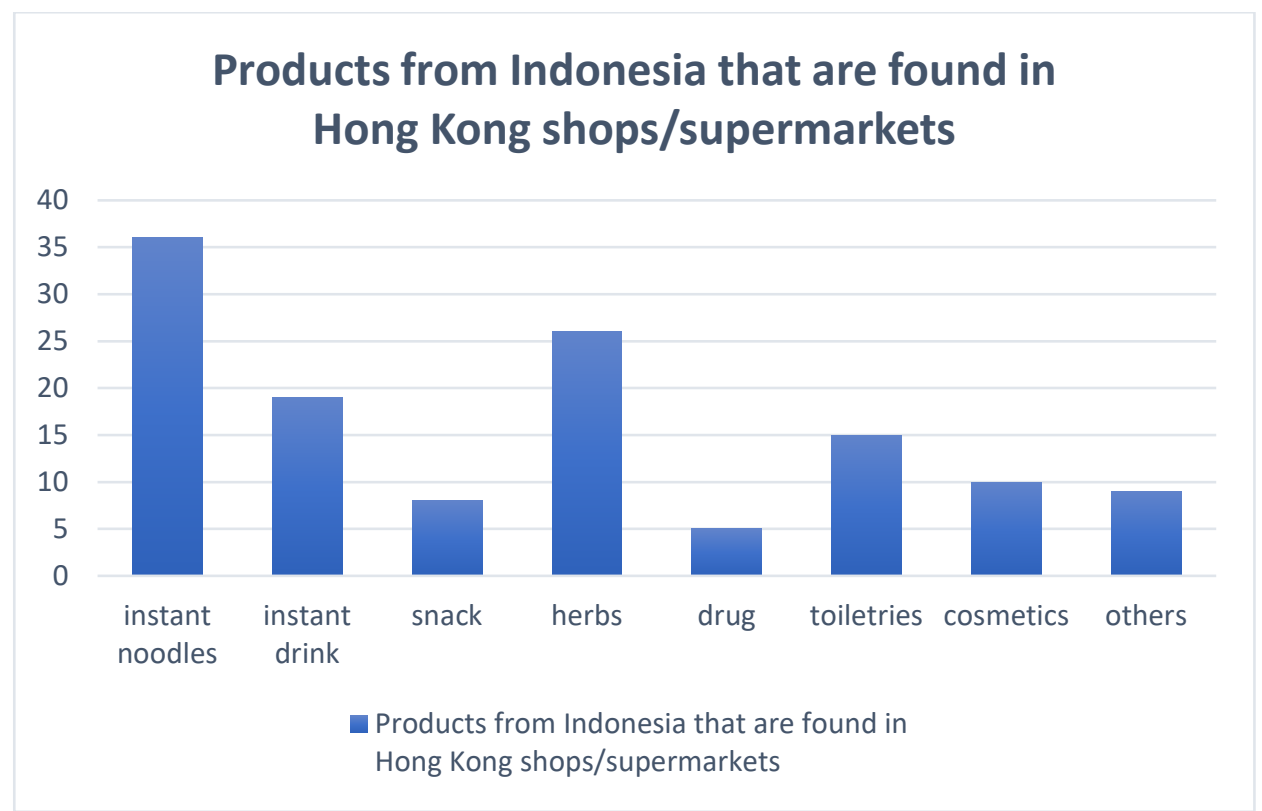

Note: each respondent may give more than one answer.

Figure 5. Categories of products from Indonesia found in shops / supermarkets Hong Kong

Indonesian-made products such as instant noodles, kitchen spices and instant drinks are indeed products that have their own export market. In Hong Kong, instant noodles made in Indonesia are quite popular with consumers. Even in every city and market in Hong Kong, there must be Indonesian shops selling Indonesian-made products (Kompasiana 2015). In addition, the quality of Indonesian herbs products has been proven in the international market. Indonesia is also trusted by other countries as a producer of the highest quality herbs. Countries such as the Middle East, Europe and East Asia are countries that often export herbs from Indonesia such as cloves, nutmeg, pepper, cinnamon, and many more (Nugroho 2019).

\section{Conclusions}

In general, the IMWs are married (46\%) and aged over 30 years to 40 years (46\%). However, $36 \%$ of them are $41-50$ years old. The majority of them have worked in Hong Kong for a long time, namely for more than 5 years to 15 years $(60 \%)$ with income ranging from more than 7 million to 9 million rupiah 
per month (72\%). Hong Kong is one of the most popular destination countries for IMWs.

If approached from a marketing point of view, IMWs is a consumer of products from Indonesia and they can also be seen as market intelligence in seeing the potential for export of products from Indonesia in Hong Kong. As many as 76 percent brought products from Indonesia when they went to Hong Kong. The reason is because they are used to using the product $(54 \%)$. The products are personal care products such as toiletries, cosmetics and medicines

The product categories brought by IMWs are included in personal care products which, in fact, will continue to be sought because of the unique characteristics of the product for each consumer. There are 88 percent of IMWs stated that they use Indonesian products in Hong Kong. The reasons for using Indonesian products in Hong Kong include feeling that they are compatible with the product $(20 \%)$, guaranteed halalness $(18 \%)$ and love for Indonesian-made products $(10 \%)$.

Identification of the export potential of products from Indonesia can be seen from the market opportunities in Hong Kong. The majority of IMWs work in families with 1-3 family members (44\%) and 4-6 people (32\%). Indirectly, IMWs user family members become the target consumers of products made in Indonesia. Most of the IMWs informed that there are products made in Indonesia in the homes where they work (56\%). The types of products most commonly found in IMWs' workplaces are kitchen spices, instant noodles, and snacks, respectively.

\section{Limitation and future research}

This research is a preliminary research which still needs further study. This research is still limited to the number of samples and market mapping in general. Future studies can be directed at assessing the demand for Indonesianmade products for consumers in Hong Kong. The concept of country of origin theory can be the basis for this research. 


\section{Acknowledgment}

We Thank you very much to Dompet Dhuafa Hongkong (DD HK), who has facilitated our interview with IMWs in Hong Kong.

\section{References}

BP2MI. 2020. Data Penempatan dan Pelindungan PMI Periode April 2020. https://bp2mi.go.id/uploads/statistik/images/data_26-052020_Laporan_Pengolahan_Data_BNP2TKI_APRIL_fix.pdf

Dompet Dhufa Hongkong: https://ddhongkong.org/profil/ (Untuk mengetahui peran LSM dalam pembinaan PMI)

Douglas P. S and Craig S. C. 2009. The role of context in assessing international marketing opportunities. International Marketing Review Vol. 28 No. 2, 2011 pp. 150-162 r Emerald Group Publishing Limited 0265-1335 DOI $10.1108 / 02651331111122641$

Guleria, Deepa. 2015. A STUDY OF CONSUMER PREFERENCE FOR SMARTPHONE: A CASE OF SOLAN TOWN OF HIMACHAL PRADESH. IJMRR/March 2015/ Volume 5/Issue 3/Article No-7/193-200. ISSN: 22497196.

Indonesia.go.id. 2019. Peran TKI hadapi krisis. https://www.indonesia.go.id/narasi/indonesia-dalam-angka/ekonomi/peran$\underline{\text { tki-hadapi-krisis. }}$

Kompasiana.

2015.

https://www.kompasiana.com/ayu25/552050ca813311a37419f73f/indomiesemakin-laris-di-hongkong-dan-paling-ngetopsejagat\#: : :text=Sekarang\%20indomie\%20tidak\%20hanya\%20dijual,orang\% 20Hongkong\%20yang $\% 20$ menjual $\% 20$ indomie.\&text $=$ Mie $\% 20$ instant $\% 20 \mathrm{~N}$ ongshim $\% 20$ shin $\% 20$ ramyun $\% 20$ juga $\% 20$ banyak $\% 20$ dijual $\% 20$ di $\% 20$ Hong kong.

Nugroho A R. 2019. 7 Rempah Khas Indonesia Ini Diekspor dengan Harga Selangit. https://hot.liputan6.com/read/3944970/7-rempah-khas-indonesia-inidiekspor-dengan-harga-selangit 